\section{Bridging the gap between customer experience management and mobile shopping}

\author{
Sonia San-Martín' \\ Nadia Jiménez ${ }^{1}$ \\ ${ }^{1}$ Universidad de Burgos, Faculty of Economics and Business, Burgos, Spain \\ Nuria Puente ${ }^{2}$ \\ ${ }^{2}$ Universidad Isabel I, Faculty of Legal and Economic Sciences, Burgos, Spain
}

Received on

10/08/2017

Approved on

$10 / 23 / 2018$

Responsible editor:

Prof. Dr. Guilherme Shiraishi

Evaluation process:

Double Blind Review

\begin{abstract}
Purpose - The purpose of this research is to study three clues (employee reputation, site design, and security) of the Customer Experience Management framework that can prompt mobile shopper satisfaction and repurchase intention. The moderator role of perceived distance of the retailer is explored.
\end{abstract}

Design/methodology/approach - The Partial Least Squares approach was employed to analyze information gathered from 1053 mobile shoppers in a geographically extensive and emerging market (Mexico).

Findings - The Customer Experience Management framework is helpful in explaining m-shopper satisfaction and intention to repurchase via mobile phone. Our findings show that reputation (particularly for consumers who perceive that retailers are near), site design (principally for consumers who perceive that retailers are far away), and security enhance mobile-shopper satisfaction. Satisfactory experiences increase repurchase intention, regardless of perceived distance of alternative retailers.

Originality/value - This study contributes to understanding which factors mobile vendors ( $\mathrm{m}$-vendors) could manage in different ways to engender satisfaction and intention to repurchase via mobile, from the unexplored Customer Experience Management perspective and in a scarcely studied emerging market. Also, a key facet of this study is related to the moderating influence of perceived distance on the relationship between employee reputation, site design, and security, on one hand, and $\mathrm{m}$-shopper satisfaction on the other.

Keywords - Mobile commerce, Customer Experience Management, satisfaction, perceived distance

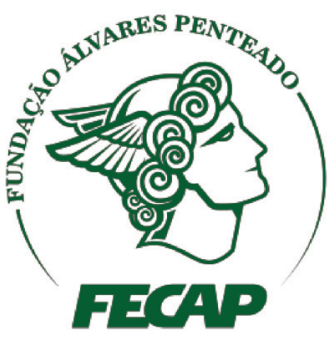

Review of Business Management

DOI:10.7819/rbgn.v21i2.3971 


\section{Introduction}

The rapid expansion of potential customer touch points and limited control over the mobile shopping experience is contributing to an increasingly complex situation in which firms create unique customer experiences and attempt to manage and control them successfully (Edelman \& Singer, 2015). The technological development of emerging countries such as Mexico, where the penetration of smartphones stands at around $20 \%$ of the population, demonstrates the growing importance of mobility. In Mexico, 91\% of smartphone users have searched for local retailer information and 51\% have searched for local business addresses of retailers or directions to their physical locations. Earlier figures reveal the importance attached to the perceived distance to alternative physical retailers in customer evaluations. This is especially relevant in a geographically extensive country where perceived distance can play an important role in customer purchase decisions. Moreover, we should not forget that Mexico is the fourteenth largest country in the world and the third largest in Latin America (National Institute of Statistic and Geography [INEGI], 2018). In this context, the management of mobile shoppers' experiences is critical, because satisfactory customer experiences can help to improve mobile business performance (Puccinelli et al., 2009). However, there is little research on Customer Experience Management (CEM) in mobile contexts, because of its novelty (Joshi, Bhatia, Raikar, \& Pall, 2017). Hence, the objective of this research is to study CEM in the mobile shopping context in more depth. More specifically, this paper aims to analyze the impact of human, mechanical, and technical clues of CEM on satisfaction and repurchase intention. This research contributes to the academic literature by applying CEM to the mobile shopping (m-shopping) context using information from 1053 real $\mathrm{m}$-shoppers and it attempts to fill the gap concerning the role that perceived distance may play. Consequently, in our proposed CEM model, the moderating influence of shopper-perceived distance (near or far) from alternative physical retailers is considered. It also contributes to managerial practice by providing firms with recommendations regarding the clues they can use to offer a satisfactory experience. This study contributes to understanding which factors mobile vendors ( $m$-vendors) could manage in different ways to engender satisfaction and repurchases via mobile.

The paper is structured into six sections. Following this introduction, in Section 2 we present the theoretical background. The justification for the proposed hypotheses is found in Section 3, and then the research method is detailed in Section 4. A discussion of the results follows in Section 5 and, finally, in Section 6 we end with our conclusions, their implications, and the limitations of our study.

\section{Theoretical framework for CEM}

From an academic perspective, customer experience is a set of activities and states of human beings, called 'experiential consumption prospects' (Ranjan \& Read, 2016). The study of customer experience in m-shopping is discussed in most cases using previously investigated theoretical perspectives [e.g. the Expectation Confirmation Theory (Pappas, Pateli, Giannakos \& Chrisskopoulos, 2014), the Technology Acceptance Model (Chong, 2013; GroB, 2015), and the Unified Theory of Acceptance and Use of Technology (Jaradat \& Rababaa, 2013; Slade, Dwivedi, Piercy \& Williams, 2015)]. However, as we have said before, research into mobile environments that incorporates the CEM framework is novel, as the vast majority of existing research contextualizes its analysis using physical retailers (Genlin \& Jie, 2015; Grewal, Levy \& Kumar, 2009; Joshi, 2014; Palmer, 2010; Sukwadi, 2015), with a few using web-based retailers (Fernández-Sabiote \& Román, 2016; Pandey \& Chawla, 2018).

CEM is the name given to the 'Total Customer Experience' strategic management 
process in a firm, which involves the firm's efforts to improve the quality of interactions with consumers in consistent and effective encounters (Joshi, 2014). An experience consists of individual contacts between the firm and the customer at distinct points in the experience, called touch points (Benzarti \& Mili, 2017; Homburg, Jozi'c \& Kuehnl, 2015; Puccinelli et al., 2009). CEM serves to structure the experiences offered to the customers, determining which clues can generate a participatory and lasting experience (Lipkin, 2016; Weber \& Elferink, 2017). Interaction through mobile phones produces clues that should be consistent and cohesive for engendering lasting and satisfactory customer experiences (Berry, Wall, \& Carbone, 2006; San-Martín, Prodanova \& López, 2016). These clues encompass not only the physical and concrete aspects of the firm, but also intangible elements (Kumar, Pozza, \& Ganesh, 2013), such as mobile store environment, security, and employee reputation. According to Berry et al. (2006), customers experience a range of clues that help them generate a set of impressions that become experiences. These authors classified clues into human, mechanical, and technical aspects.

Berry et al. (2006) characterized human clues as those emanating from people, while Lipkin (2016) affirmed that they consisted of relational elements in the context of new technologies, such as interactions with other customers and the employees of the firm. According to Fatma (2014), customers' interactions with the employees of a firm affect customer perceptions. According to Berry et al. (2006), this clue refers to the behavior of providers, in our case reflected in the employee reputation of the m-vendor firm. Reputation can clearly reflect the past performance of an m-vendor's customer service, which would suggest that $\mathrm{m}$-vendor employees gain knowhow in managing satisfactory experiences (Choi \& Nazareth, 2014). Consumers may be more likely to buy when m-vendors have employees (e.g. customer service) with a good reputation for providing satisfactory $\mathrm{m}$-shopping experiences (González-Hernández \& OrozcoGómez, 2012). In contrast, Hillman and Neustaedter (2017) pointed out that a lack of social clues (e.g. reputation) from the employees in mobile commerce reduced mobile shopping development. Thus, it is especially important to consider the human attention provided during the customer mobile experience.

Regarding the mechanical clue of CEM, Berry et al. (2006) described it as comprising diverse environment clues that concern the 'sensory' presentation of the service (e.g. design, ambient conditions, signs, and symbols). Kimbell (2011) noted the importance of design issues when developing or managing customer experiences. Likewise, Simons, Hampe, and Guldemond (2014) stated that paying greater attention to the details of the mechanical artifacts involved in a service experience will impact on customer satisfaction. According to Blut, Chowdhry, Mittal, and Brock (2015), these factors show a greater impact on the perception of service quality than the intangible aspects of the environment. Customers will usually first perceive the clue that helps to create an initial positive impression (Berry et al., 2006). In our study, this clue will refer to the mobile website ( $\mathrm{m}$-site) environment or design, i.e., the sum of the virtual mechanical signals that the user perceives during the shopping experience on the mobile website.

The technical clue of CEM refers to customer perceptions of the technical performance of the service that is provided and is known as the functional part of the CEM framework, which includes the calculative perception of quality (Berry et al., 2006; Mbama \& Ezepue, 2018). It refers to "the subjective probability with which consumers believe that their personal information will not be viewed, stored, and manipulated during transit and storage by inappropriate parties in a manner consistent with their confident expectations" (Flavián \& Guinalíu 2006). According to Mai, Yoshi, and Tuan (2014), in emerging markets, customers' trust in virtual transactions is not strong. Therefore, the 
mission of web designers is to create an attractive interface, updating the latest information, and the security systems, thus enhancing the perception of usefulness among customers. However, few studies have investigated the above-mentioned cognition related to determinants of trust and satisfaction in online contexts in emerging markets.

In addition, the psychologically perceived distance to physical stores can make differences in the impact of previous clues of CEM on satisfaction and repurchase intention. Darke, Brady, Benedicktus, and Wilson (2016) state the importance of this perceived distance. Although to the best of our knowledge there are no works addressing this influence of perceived distance in an online shopping context, it is considered here as a key variable when speaking about shopping online or offline.

\section{Proposed hypotheses}

One of the most crucial variables in CEM is satisfaction, as it is the result of a good and complete experience (Joshi, 2014). Satisfaction is a relational variable that has been studied in the context of mobile commerce (Chi, 2018; Deng, Lu, Wei, \& Zhang, 2010). It implies fulfilling expectations as well as a positive affective state, based on the result of maintaining a relationship in the mobile context (Fernández-Sabiote $\&$ Román, 2016). Satisfaction also impacts on customer loyalty as well as purchase intention (Kuo, Wu, \& Deng, 2009). In mobile commerce, which is a new and still unexplored medium of buying and selling for many customers, satisfaction is key if relations are to be maintained, bearing in mind that initial commercial experiences may set the tone for a firm's success or failure in this medium. Several studies have highlighted the importance of exploring determinants of $\mathrm{m}$-shopper satisfaction (Choi, Seol, Lee, Cho, \& Park, 2008; Kuo et al., 2009). On this point, Sharma, Wu, and $\mathrm{Su}$ (2016) found that satisfaction is driven by the efforts of employees and firm performance during a service encounter, which impacts on the behavioral intentions of the customer. The authors considered the human-technical-mechanical triad of CEM when considering antecedents of m-shopper satisfaction.

\section{I Clues of CEM in m-shopping}

Regarding the human clue of CEM, De Keyser, Lemon, Klaus, and Keiningham (2015) described customer experience as "comprised of the cognitive, emotional, physical, sensorial, spiritual, and social elements that mark the customer's direct or indirect interaction with (an) other market actor(s)" - in essence, the raw data contained in all direct or indirect interactions that then come together as an overall experience. Consumers are more likely to buy when vendors have a good reputation, because this clue emerges from m-vendor behavior (Berry et al., 2006). According to Fiore and Kim (2007) and GroB (2015), the perception of being a good m-provider positively affects intention to purchase via mobile. In addition, reputation has a positive influence on customer experience (Joshi, 2014).

\section{H1. The reputation of the employees of the $m$-vendor positively influences $m$-shopper satisfaction.}

In regard to the mechanical clue of CEM, Kamaladevi (2010) said that consumer spending behavior can be significantly influenced by the store atmosphere. Customers require a store layout that maximizes the number of products seen within the context of a customers' need for the product. Good site design can lead to more purchases, especially if products are presented within a display that shows the potential usefulness of the product for them. In mobile contexts, users come to recognize the process and services through repeated use of $\mathrm{m}$-sites, searching for product information and requesting assistance. Cyr, Head, and Ivanov (2006) and Li and Yeh (2010) suggested that aesthetics might be an important part of designing an overall satisfactory user experience with mobile devices. 
Joshi (2014) also pointed out that design is an essential factor for improving customers' lasting and enjoyable experiences. Thus, it is proposed here that $\mathrm{m}$-site design has positive effects on customer satisfaction, as previously suggested by Kim, Chung, Lee, and Preis (2015).

\section{H2. M-site design positively influences} m-shopper satisfaction.

In our research, the technical clue of CEM will focus on security, an important element of electronic transactions, which is still minimal in the case of mobile phones. Ray, Ow, and Kim (2011) argued that security is a highly technical characteristic not commonly interpretable by users. However, customers' perceptions of a vendor's security mainly influence customers' satisfaction, because users of electronic devices (such as mobile phones) usually lack knowledge of security technologies or make little or no effort to analyze security documentation (Choi \& Nazareth, 2014). In this hyper-connected world, mobile phone use for shopping is associated with low security, which in turn involves less shopping intention, as shown by Slade et al. (2015). In this sense, Choi et al. (2008) and Khatun and Ruhul Islam (2018) stated that security is a crucial variable in mobile commerce and a technical clue that is essential in driving shoppers' satisfaction.

H3. M-site security positively influences m-shopper satisfaction.

\subsection{The relationship between satisfaction and repurchase intention}

Returning to the concept of 'Total Customer Experience', the foundation of the CEM strategy, it is necessary to focus attention on the fact that this has to be positive. When researching customer experience, satisfaction is an unavoidable topic, since a key for a retailer to be successful is to meet the needs of customers better than its competitors and beneficially for both customer and firm. In this context, proper management of customer expectations, to ultimately achieve customer repurchase intention, is essential (Chong, 2013). Satisfied $\mathrm{m}$-shoppers express a higher intention to repeat purchases (Lin \& Bennett, 2014). In the specific case of mobile commerce, Agrebi and Jallais (2015) found that satisfaction directly influences repurchase intention.

H4. M-shopper satisfaction positively influences his/her repurchase intention.

\subsection{The psychological distance to alternative physical retailers as a moderating variable}

Psychological distance is a variable of interest in understanding mobile-based purchases (Memery, Angell, Megicks, \& Lindgreen, 2015). It refers to the distance of a stimulus from the perceiver's direct experience (Darke et al., 2016). In this paper, attention is placed on spatially perceived distance; the subjective consideration of nearness or distance of a consumer in relation to a physical store, irrespective of the real distance (i.e. in kilometers) between the consumer and the store. Even if two consumers live at the same objective distance to physical stores, they can perceived this distance in a different way, as near or far, and this perception can determine their attitude and shopping intention. Forman, Ghose, and Goldfarb (2009) suggested that the distance to alternative physical retailers appears to shape consumers' channel choice. Since previous studies have found that physical distance separation can be mitigated by reducing psychological distance (Darke et al., 2016), it is interesting to determine the role of perceived distance in CEM.

Construal Level Theory has been used to examine how consumers respond to perceived distances and to suggest that consumer judgment is partly explained by psychological distance from retailers (Katz \& Byrne, 2013; Liberman, Trope, $\&$ Stephan, 2007). In fact, psychological distance could be even more important to understand 
electronic consumer evaluations than physical distance (e.g. miles or kilometers) (Darke et al., 2016). In the case of consumers who have to travel large distances to retailers that provide them with the goods needed, m-shopping could be a sustainable alternative to overcome this perceived lengthy distance (Perea-Monsuwé, Dellaert, \& De Ruyter, 2004). Grewal et al. (2009) also identified perceived distance as one of the key drivers for CEM's service delivery. Nevertheless, the moderating effect of this variable has almost been ignored in the previous literature (Lin \& Bennett, 2014). Therefore, it is interesting to explore the differences that perceived distance produces in the impact of CEM clues on satisfaction and repurchase intention. It is proposed that perceived distance to alternative physical retailers has a moderating role.

H5. M-shopper perceived distance to alternative physical retailers has a moderating effect on the relationships previously proposed in $\mathrm{H} 1, \mathrm{H} 2, \mathrm{H} 3$, and $\mathrm{H} 4$.

Following the reasoning above, the model proposed here is shown in Figure 1.

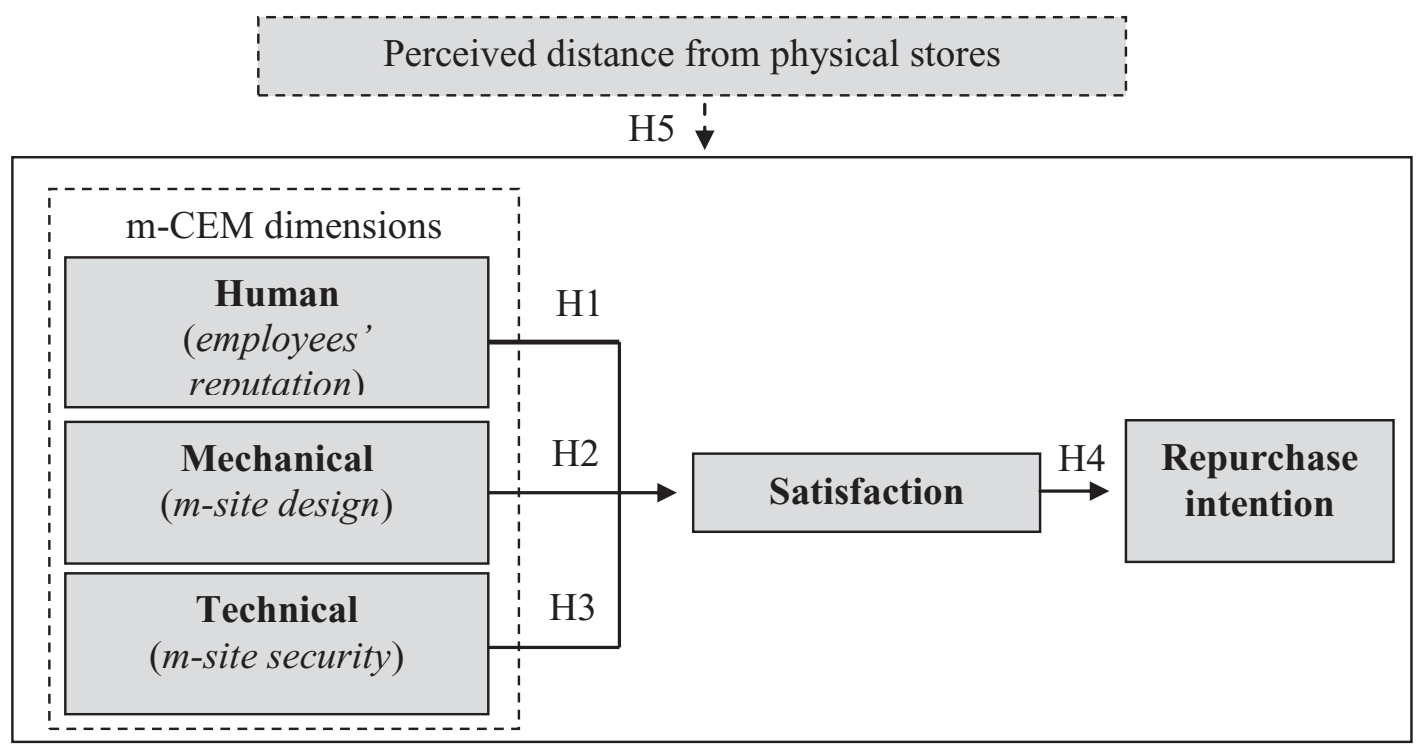

Figure 1. Proposed m-CEM framework

\section{Methodology}

\section{I Description of the sample}

The empirical study is based on information gathered through personal interviews with Mexican mobile phone users, who have previously bought at least once via mobile phone. We selected Mexico to test the proposed model, because it represents an emerging market with potential for mobile commerce. According to Mexican Internet Association (AMIPCI) (2016), the Mexican mobile market has an estimated value of over 150 million dollars. A systematic sampling method was employed to select a list of mobile phone numbers from a national panel of mobile users. The users were contacted by phone and invited to participate in a subsequent telephone survey (following the CATI-Computer Assisted Telephone Interviews system) on their most recent purchase on a mobile website. The individuals were part of a panel of mobile phone users in each country. From 1800 attempts, 1053 valid questionnaires were personally collected. The 
profile of the final sample is described in Table 1 and was similar to the scarce data available on mobile shoppers' profiles (e.g. 52\% are male and $78 \%$ belong to the millennial generation) (AMIPCI, 2016).

Table 1

\section{Sample characteristics}

\begin{tabular}{lll}
\hline \multicolumn{1}{c}{ Characteristic: percentage (\%) } \\
\hline Gender & Male: $\mathbf{5 6 . 7 \%}$ & Female: $\mathbf{4 3 . 3} \%$ \\
\hline \multirow{3}{*}{ Age } & Under $18: 10.5 \%$ & $35-44: 6.2 \%$ \\
& $18-24: 59.2 \%$ & $45-54: 3.1 \%$ \\
& $25-34: 20.7 \%$ & $55-64: 0.3 \%$ \\
\hline \multirow{3}{*}{ Occupation } & Student: $52.9 \%$ & House worker: $2.2 \%$ \\
& Employee: $34.9 \%$ & Retired: $0.90 \%$ \\
\hline \multirow{3}{*}{$\begin{array}{l}\text { Mobile vendor with an alternative physical } \\
\text { retailer (last purchase) }\end{array}$} & Technology and electronic devices: $34.9 \%$ & Books: $4.5 \%$ \\
& Multimedia content: $30 \%$ & Software: $3.5 \%$ \\
& Mobile phone communication: $15.4 \%$ & Travel service: $3.3 \%$ \\
& Clothes: $5.7 \%$ & Mobile banking: $2.7 \%$ \\
\hline
\end{tabular}

In order to ensure content validity, 5-point Likert scales were used, taking the literature review as a reference and following prior studies in their use of five-point scales (i.e. Johnson, Kiser, Washington, \& Torres, 2018 or SanMartín, Prodanova, \& Jiménez, 2015). Items were adapted to m-shopping with the help of in-depth interviews with a convenience sample of five vendors and experts, who were chosen because of their specialized experience in online and mobile selling, since they were web and mobile site designers or sold their products on online and mobile websites. According to Heo and Kim (2016), an expert is a person who has work experience that can cover various aspects of the mobile industry. Specifically, from among the five experts, one has over nine years' experience in a start-up company for e-tailing; another two have been working for four years in a major marketing association regularly publishing statistical data on electronic commerce in Mexico; the fourth is an apps developer in a mobile device company; and, finally, the other is a marketing consultancy manager with over five years' experience. Thus, in line with past research (Lin \& Bennett, 2014), as CEM clues are relatively new, and no established items are available, the interviewed vendors and experts were asked about the variables that best fit with each definition of each CEM clue. As Kowalski, Giumetti, Schoeder, and Lattanner (2014) stated, the domain of interest must first be defined, and then items that map onto that definition must be developed and tested. Consequently, reputation, design, and security are the most frequently mentioned CEM clues and are identified as human, mechanical, and technical $m$-vendor characteristics in an association test with experts. All items were first written in English and then translated into Spanish using the direct translation protocol (Piacentini \& Cui, 2010). A pilot test of the Spanish version of the questionnaire was conducted with the collaboration of 12 regular $\mathrm{m}$-shoppers, and some amendments were made in relation to local expressions (e.g. cellular instead of mobile phone). Regarding measurements, the reputation scale (human clue) was taken from Qureshi et al. (2009) and Jarvenpaa, Tractinsky, and Vitale (1999). Perceived security (technical clue) was measured using the scale from Luarn and Lin (2005) and Schierz, Schilke, and Wirtz (2010) as a reference. The design measures (mechanical clue) were based on the studies by Cyr et al. (2006), Montoya-Weiss, Voss, and Grewal (2003), 
and Harris and Goode (2004). Satisfaction was measured using the scale proposed by MontoyaWeiss et al. (2003) and Harris and Goode (2004) as references. Studies from Harris and Goode (2004) and Morosan (2014) were followed to measure repurchase intention. The items are presented in the Appendix. Most researchers agree that Common Method Variance (CMV) reflects potentially serious bias in behavioral research, especially with surveys. The latent factor method was therefore employed to establish problems of common method bias (Malhotra, Kim, \& Patil, 2006). It involves adding a latent variable that represents the common method. In this technique, all manifest variables were related to the latent method variable, their paths were constrained to be equal, and the variance of the common factor was constrained to be 1 . The results revealed that the variance accounted for by the common method latent variable was only $3.4 \%$ of the total variance. So, this result suggests that common method variance is unlikely to affect the findings of this study.

\subsection{Measurement analyses}

Initially, exploratory factor analysis (EFA) was conducted to observe the unidimensionality of the latent variable measurements (Table 2).

Table 2

\section{Exploratory factor analysis results}

\begin{tabular}{|c|c|c|c|c|c|}
\hline Latent variable & Item & Skewness & Kurtosis & EFA weight & \% Explained variance \\
\hline \multirow{5}{*}{ Employees' reputation } & R1 & -0.741 & -0.399 & 0.745 & \multirow{5}{*}{9.92} \\
\hline & $\mathrm{R} 2$ & -0.417 & -0.612 & 0.752 & \\
\hline & R3 & -0.326 & -0.409 & 0.717 & \\
\hline & $\mathrm{R} 4$ & -0.398 & -0.447 & 0.752 & \\
\hline & $\mathrm{R} 5$ & -0.546 & -0.365 & 0.679 & \\
\hline \multirow{4}{*}{$\mathrm{m}$-site design } & D6 & -0.271 & -0.655 & 0.653 & \multirow{4}{*}{5.45} \\
\hline & D7 & -0.279 & -0.603 & 0.719 & \\
\hline & D8 & -0.394 & -0.582 & 0.773 & \\
\hline & D9 & -0.535 & -0.483 & 0.721 & \\
\hline \multirow{4}{*}{ m-site security } & S10 & -0.068 & -1.109 & 0.819 & \multirow{4}{*}{8.26} \\
\hline & S11 & -0.113 & -0.869 & 0.890 & \\
\hline & $\mathrm{S} 12$ & -0.095 & -0.954 & 0.883 & \\
\hline & S13 & -0.148 & -0.850 & 0.716 & \\
\hline \multirow{7}{*}{ Satisfaction } & SA14 & -0.537 & -0.464 & 0.751 & \multirow{7}{*}{41.25} \\
\hline & SA15 & -0.541 & -0.316 & 0.757 & \\
\hline & SA16 & -0.495 & -0.341 & 0.769 & \\
\hline & SA17 & -0.444 & -0.402 & 0.804 & \\
\hline & SA18 & -0.557 & -0.338 & 0.794 & \\
\hline & SA19 & -0.464 & -0.305 & 0.764 & \\
\hline & SA20 & -0.520 & -0.419 & 0.743 & \\
\hline \multirow{3}{*}{ Repurchase intention } & P21 & -0.285 & -0.679 & 0.821 & \multirow{3}{*}{4.69} \\
\hline & $\mathrm{P} 22$ & -0.192 & -0.609 & 0.729 & \\
\hline & P23 & -0.297 & -0.566 & 0.706 & \\
\hline
\end{tabular}

The structural equation model was estimated and tested by using partial least squares (PLS) due to this method's advantages. PLS is distribution-free, and it is a robust and powerful method for exploratory applications (Henseler,
Hubona, \& Ray, 2016; Hair, Hult, Ringle, \& Sarstedt, 2013). The values related to asymmetry and kurtosis led us to suspect that the sample does not present normality (for details see Table 2) (Pallant, 2016), thus we proceeded to use 
SmartPLS, which is a non-parametric analysis software. Following the recommendations of Hair, Ringle, and Sarstedt (2011) and Hair, Hult, Ringle Sarstedt, and Thiele (2017), it was considered that the most appropriate estimation method would be the bootstrapping method (5000 subsamples) (Hair et al., 2017).

We followed the recommended two-stage analytical procedure for the PLS approach to structural equation modeling (Hair et al., 2013; Henseler et al., 2016). First, the measurement model was evaluated. Second, the structural model was evaluated, including estimation and testing of the model. In both stages, the software used was SmartPLS 3.0 (Hair et al., 2013). The extent to which the observed variables measured their underlying construct was tested by their loadings ( $>0.5)$ and the t-Student statistic value (>1.96 with a confidence level of 95\%). We were therefore able to confirm the significance of all the indicators, thereby ensuring their convergent validity. The corresponding Cronbach's alpha $(\alpha)$ coefficients and composite reliability (CR) coefficients were calculated to determine the reliability of the final scales, and in all cases, their respective values were greater than 0.70 and 0.60 , which confirms that the scales are reliable and have internal consistency (Bagozzi \& Yi, 1988). The average variance extracted (AVE), which was greater than 0.5 in each case, shows the overall quantity of variance for each item that is explained by the latent constructs (Bagozzi \& Yi, 1988). The results of the measurement model are shown in Table 3.

Table 3

\section{Confirmatory factor analysis results}

\begin{tabular}{|c|c|c|c|c|c|c|}
\hline Latent variable & Item & Loadings & t-value & AVE & $\mathrm{CR}$ & $\alpha$ \\
\hline \multirow{5}{*}{ Employees' reputation } & $\mathrm{R} 1$ & $0.755^{* * *}$ & 46.61 & \multirow{5}{*}{0.64} & \multirow{5}{*}{0.90} & \multirow{5}{*}{0.86} \\
\hline & $\mathrm{R} 2$ & $0.805^{* * *}$ & 52.65 & & & \\
\hline & R3 & $0.788^{* * *}$ & 53.75 & & & \\
\hline & $\mathrm{R} 4$ & $0.841^{* * *}$ & 72.21 & & & \\
\hline & R5 & $0.796^{* * *}$ & 53.70 & & & \\
\hline \multirow{4}{*}{ m-site design } & D6 & $0.732^{* * *}$ & 32.51 & \multirow{4}{*}{0.64} & \multirow{4}{*}{0.87} & \multirow{4}{*}{0.81} \\
\hline & D7 & $0.796^{* * *}$ & 51.15 & & & \\
\hline & D8 & $0.837^{* * *}$ & 64.70 & & & \\
\hline & D9 & $0.816^{* * *}$ & 54.81 & & & \\
\hline \multirow{4}{*}{ m-site security } & S10 & $0.821^{* * *}$ & 50.79 & \multirow{4}{*}{0.74} & \multirow{4}{*}{0.92} & \multirow{4}{*}{0.88} \\
\hline & S11 & $0.894^{* * *}$ & 95.47 & & & \\
\hline & S12 & $0.884^{* * *}$ & 94.03 & & & \\
\hline & S13 & $0.836^{* * *}$ & 69.15 & & & \\
\hline \multirow{7}{*}{ Satisfaction } & SA14 & $0.842^{* * *}$ & 79.43 & \multirow{7}{*}{0.71} & \multirow{7}{*}{0.95} & \multirow{7}{*}{0.93} \\
\hline & SA15 & $0.849^{* * *}$ & 78.72 & & & \\
\hline & SA16 & $0.837^{* * *}$ & 69.96 & & & \\
\hline & SA17 & $0.854^{* * *}$ & 82.77 & & & \\
\hline & SA18 & $0.852^{* * *}$ & 85.68 & & & \\
\hline & SA19 & $0.836^{* * *}$ & 66.58 & & & \\
\hline & SA20 & $0.827^{* * *}$ & 68.68 & & & \\
\hline \multirow{3}{*}{ Repurchase intention } & P21 & $0.787^{* * *}$ & 53.55 & \multirow{3}{*}{0.63} & \multirow{3}{*}{0.91} & \multirow{3}{*}{0.88} \\
\hline & P22 & $0.818^{* * *}$ & 63.26 & & & \\
\hline & $\mathrm{P} 23$ & $0.842^{* * *}$ & 91.21 & & & \\
\hline
\end{tabular}


Regarding the assessment of discriminant validity, Henseler, Ringle, and Sarstedt (2015) and Voorhees, Brady, Calantone, and Ramirez (2016) agreed that the Heterotrait-Monotrait (HTMT) ratio is a clear and rigorous approach. The HTMT ratio showed values lower than 0.85 , a threshold recommended by Henseler et al. (2016) to assure discriminant validity. It was also assessed by verifying that the square root of the average variance extracted for each construct exceeded its correlation with any other latent variable (Fornell \& Larcker, 1981) (Table 4).

Table 4

Heterotrait-monotrait (HTMT) ratio of correlations and matrix correlations

\begin{tabular}{lccccc}
\hline & $\mathbf{1}$ & $\mathbf{2}$ & $\mathbf{3}$ & $\mathbf{4}$ & $\mathbf{5}$ \\
\hline Employees' reputation & 0.797 & 0.550 & 0.381 & 0.540 & 0.458 \\
m-site design & 0.662 & 0.787 & 0.312 & 0.533 & 0.486 \\
m-site security & 0.427 & 0.362 & 0.859 & 0.377 & 0.335 \\
Satisfaction & 0.606 & 0.609 & 0.412 & 0.847 & 0.687 \\
Repurchase intention & 0.518 & 0.567 & 0.362 & 0.757 & 0.793 \\
\hline
\end{tabular}

Note: Values above diagonal represent correlations between constructs, values in the diagonal (in italic) represent the square root of the AVE, and values under the diagonal represent HTMT ratio correlations.

\subsection{Structural model estimation}

After validating the measurement model (Table 4), we used SmartPLS 3.0 (Hair et al., 2011; Hair et al., 2017) to estimate the structural model. The standardized root mean square residual (SRMR) was 0.053. For the model fit criteria, Henseler et al. (2016) suggested that SRMR should be less than 0.08 to be adequate for PLS path models. The statistics provided by the results of the analysis included the path coefficient $(ß)$, t-value, Cohen's $\mathrm{f}^{2}$, and $\mathrm{R}^{2}$, as presented in
Table 5. According to Cohen (1988), f2 $\geq 0.02$, $\mathrm{f} 2 \geq 0.15$, and $\mathrm{f} 2 \geq 0.35$ represent small, medium, and large effect sizes, respectively. In addition, it was confirmed that the $\mathrm{R}^{2}$ of the dependent variables exceeds 0.1 , thus supporting all the hypotheses (Hair et al., 2013). According to the results (Table 5), all clues of CEM have a positive effect on $\mathrm{m}$-shopper satisfaction and satisfaction engenders $\mathrm{m}$-shopper repurchase intention. Hence, none of the proposed hypotheses are initially rejected.

Table 5

Structural model and hypotheses testing

\begin{tabular}{lccc}
\hline Path & B & t-value & Cohen's f2 \\
\hline Employees' reputation $\rightarrow$ Satisfaction $(\mathrm{H} 1)$ & $0.311^{* * *}$ & 8.710 & 0.104 \\
m-site design $\rightarrow$ Satisfaction $(\mathrm{H} 2)$ & $0.305^{* * *}$ & 8.692 & 0.105 \\
$\mathrm{~m}$-site security $\rightarrow$ Satisfaction (H3) & $0.170^{* * *}$ & 5.889 & 0.040 \\
Satisfaction $\rightarrow$ Repurchase intention $(\mathrm{H} 4)$ & $0.694^{* * *}$ & 33.304 & 0.927 \\
\hline $\mathrm{R}^{2}$ Satisfaction & & 0.390 & 0.481 \\
$\mathrm{R}^{2}$ Repurchase intention & & 0 & \\
\hline
\end{tabular}

Note. $\beta$ : path coefficient; ${ }^{* * *} \mathrm{p}<0.01 ;{ }^{* *} \mathrm{p}<0.05 ;{ }^{*} \mathrm{p}<0.10$ 
A multi-group model was estimated taking into account the moderating effect of perceived distance to alternative physical retailers [e.g. a dichotomous scale of customers' perceived distance (near/far) from physical stores]. 61.4\% of the sample of $\mathrm{m}$-shoppers affirmed their perceptions of physical stores as being nearby. According to the Welch-Satterthwait MGA statistic, the results showed that there is a moderating effect of perceived distance in the relationships between both human and mechanical clues of CEM and satisfaction at a 95\% confidence level and between the technical clue of CEM and satisfaction at a 90\% confidence level (Table 6).

Table 6

\section{PLS multi-group analysis and Welch-Satterthwait Test}

\begin{tabular}{|c|c|c|c|c|c|c|}
\hline \multirow[t]{2}{*}{ Path } & \multicolumn{2}{|c|}{$\begin{array}{c}\text { Group }_{(\text {Near }}: \\
n=647\end{array}$} & \multicolumn{2}{|c|}{$\begin{array}{c}\text { Group }_{\text {(Far) }} \text { : } \\
4^{2}\end{array}$} & \multicolumn{2}{|c|}{ Welch-Satterthwait Test } \\
\hline & $\boldsymbol{\beta}_{\text {(Near) }}$ & t-value & $\boldsymbol{\beta}_{(\mathrm{Far})}$ & t-value & |Difference $\mid$ & p-Value \\
\hline Employees' reputation $\rightarrow$ Satisfaction $(\mathrm{H} 1)$ & $0.408^{* * *}$ & 7.07 & $0.314^{* * *}$ & 5.63 & 0.006 & $0.046^{* *}$ \\
\hline m-site design $\rightarrow$ Satisfaction $(\mathrm{H} 2)$ & $0.312^{* * *}$ & 7.31 & $0.428^{* * *}$ & 5.53 & 0.006 & $0.038^{* *}$ \\
\hline m-site security $\rightarrow$ Satisfaction (H3) & $0.147^{* * *}$ & 4.81 & $0.201^{* * *}$ & 4.41 & 0.054 & $0.068^{*}$ \\
\hline Satisfaction $\rightarrow$ Repurchase intention $(\mathrm{H} 4)$ & $0.658^{* * *}$ & 23.2 & $0.655^{* * *}$ & 16.9 & 0.003 & 0.360 \\
\hline $\mathrm{R}^{2}$ (Near) Satisfaction & \multicolumn{6}{|c|}{0.390} \\
\hline $\mathrm{R}_{\text {(Near) }}^{2}$ Repurchase intention & \multicolumn{6}{|c|}{0.433} \\
\hline $\mathrm{R}_{(\mathrm{Far})}^{2}$ Satisfaction & \multicolumn{6}{|c|}{0.423} \\
\hline $\mathrm{R}_{(\mathrm{Far})}^{2}$ Repurchase intention & \multicolumn{6}{|c|}{0.429} \\
\hline
\end{tabular}

Note. $\beta$ : path coefficient; ${ }^{* * *} \mathrm{p}<0.01 ;{ }^{* *} \mathrm{p}<0.05 ;{ }^{*} \mathrm{p}<0.10$

Although it was not the main objective of this research, we also estimated the mediating effect of satisfaction between CEM clues and repurchase intention. According to the results, indirect effects are significant, and the strength of the mediation effect is assessed by using the VAF (Variance Accounted For) (Table 7). The VAF indicated that more than $50 \%$ of the three CEM clues are explained by satisfaction as a mediator (Hair et al., 2013).

Table 7

\section{Mediation analysis results}

\begin{tabular}{|c|c|c|c|c|c|c|}
\hline \multirow[t]{2}{*}{ Path } & \multicolumn{2}{|c|}{$\begin{array}{c}\text { Group }_{\text {(Near) }} \text { : } \\
n=647\end{array}$} & \multicolumn{2}{|c|}{$\begin{array}{c}\text { Group }_{\text {(Far) }} \text { : } \\
\text { : }\end{array}$} & \multirow{2}{*}{$\begin{array}{c}\text { Group }_{\text {(Near) }} \\
\text { VAF }\end{array}$} & \multirow{2}{*}{$\begin{array}{c}\text { Group }_{(\mathrm{Far})} \\
\text { VAF }\end{array}$} \\
\hline & Total effect & t-value & Total effect & t-value & & \\
\hline Employees' reputation $\rightarrow$ Repurchase intention & $0.253^{* * *}$ & 4.84 & $0.247^{* * *}$ & 4.25 & $65 \%$ & $71 \%$ \\
\hline m-site design $\rightarrow$ Repurchase intention & $0.304^{* * *}$ & 6.65 & $0.206^{* * *}$ & 3.26 & $51 \%$ & $86 \%$ \\
\hline m-site security $\rightarrow$ Repurchase intention & $0.174^{* * *}$ & 4.76 & $0.221^{* * *}$ & 4.62 & $41 \%$ & $51 \%$ \\
\hline
\end{tabular}

Note. ${ }^{* * *} \mathrm{p}<0.01 ;{ }^{* *} \mathrm{p}<0.05 ;{ }^{*} \mathrm{p}<0.10$ 


\section{Discussion}

Customer satisfaction and repurchase intention are derived from selective perception and retention of different clues that customers experience when purchasing using a mobile phone. In this sense, our results are relevant for mobile contexts, to determine the effect of different components on m-shoppers' experience management. In general, managers would benefit from this research by being able to ascertain which components and clues of customer experience make the most significant contributions to customer retention. This study has shown the significant and relevant influence of three components of CEM (human, mechanical, and technical) on m-shoppers' satisfaction. Moreover, the results show that the size of the effect of each clue varies depending on the customer-perceived (psychological) distance to alternative physical retailers. This constitutes valuable evidence in a competitive context where every day more and more retailers are pressured to offer their products and services through a new channel (such as the mobile phone one). This finding is particulary interesting since perceived distance works as a moderator of the determinants of $\mathrm{m}$-shopper satisfaction in the mobile context. More specifically, the results of this study suggest that the human CEM clue (m-vendor's reputation) is the main clue that determines the m-shopper's satisfaction, if perceived distance is short, but the mechanical CEM clue (m-site design) becomes the main clue that determines the m-shopper's satisfaction, if perceived distance is large. It is interesting to note this moderating effect of psychological distance, because if it is not examined, managers and marketers could be investing efforts and money into all clues without empirical evidence that supports their decisions. In the mobile commerce context, our evidence has supported former studies, which affirm that customer perception of employees' efforts in delivering a good service has a strong impact on satisfaction (Mohr \& Bitner, 1995), but only for those m-shoppers who perceive alternative physical retailers as being nearby. The analyzed human clue has a greater effect on customers' satisfaction with $\mathrm{m}$-shopping when they perceive that alternative physical retailers are nearer to them than when consumers perceive they are far away. This could be explained by the customers' feeling of having the possibility of choosing between shopping by mobile phone or at a store. This result supports the previous findings of Fernández-Sabiote and Román (2016), which suggest that when customers perceive easy access to a multi-channel service, their expectations of what they are going to receive from the firm's employees is higher than when they only interact with a mobile vendor. Therefore, it will be more difficult to fulfill those customers' expectations, compared to other customers who have less interaction with frontline employees, because they perceive a huge psychological distance from retailers. Likewise, the impact on satisfaction of the mechanical clue under analysis is greater when consumers perceive that retailers are far away from them. According to previous literature, environmental clues trigger the perception that the $\mathrm{m}$-vendor has the organizational infrastructure required to support purchases by mobile phone (Bonera, 2011). In this sense, $\mathrm{m}$-site mechanical clues are powerful sources of sensory images, sounds, and messages that can help customers to visualize firms' products and services, and this clue can increase their satisfaction with m-shopping, especially when customers cannot a priori touch or test firms' products. In agreement with Darke et al. (2016), our results suggest that environmental clues act as an effective m-vendor strategy that reduces psychological distance. If a customer feels isolated from alternative physical retailers, a stimulating $\mathrm{m}$-site design will be crucial for a satisfactory experience, because it will be the main or the only channel that will contribute to developing that customer's experience. In line with previous evidence from Fernández-Sabiote and Román (2016), clues in the ambience of electronic channels have a stronger influence on 
satisfaction building for customers who consider mobile purchases as a substitute for offline purchases (this is the case of the customer who perceives alternative physical retailers as being far away) than for those who consider the channels as complementary (in the case of customers who perceive alternative physical retailers as being nearby). Complementary to the previously mentioned clues, the technical aspects are also essential to have satisfied m-shoppers. According to Berry et al. (2006), technical factors are functional clues that reveal the reliability, safety, and competence of firms that want to maintain loyal customers. In the mobile context, it could be assumed that the analyzed technical clue (m-site security) is a necessary condition to compete in the mobile market irrespective of the customer's perceived distance to alternative physical retailers. However, it is the clue that has the smallest effect on determining $\mathrm{m}$-shoppers' satisfaction; its effects do not vary with the customer's perception regarding distance. Therefore this clue should be considered as a basic clue that any $\mathrm{m}$-vendor has to manage, in order to have satisfied m-shoppers. According to Heo and Kim (2016), security is essential for mobile services, especially when firms manage personal information (such as location) to improve the service experience. This argument might explain why the perceived distance to retailers has no robust moderating effect on the relationships between technical clues and m-shoppers' satisfaction. It is an important result, because $\mathrm{m}$-shoppers perceive that the protection of all their personal information is a key clue to be satisfied, and because customers have more personal information on their mobile phones. In fact, a mobile phone is a personal tool that acts as a personal assistant in the personal and professional life of the customer. According to Lee, Yang, Lee, and Lee (2015), customers view security as a requisite in electronic services, and as they are becoming more security-aware, security has become a must. Finally, our results have provided support to previous studies (Lin \& Wang, 2006) that find a positive effect of $m$-shopping satisfaction on intention to repurchase via mobile phone, irrespective of customers' perceived distance to alternative physical retailers. Thus, satisfaction plays a mediating role between CEM clues and repurchase intention, as our empirical results have confirmed. Satisfaction is therefore the path towards getting $\mathrm{m}$-shoppers to repurchase, but there are three different elements (human, mechanical, and technical) that have to be managed by an m-vendor in an acceptable combination in accordance with the $\mathrm{m}$-shopper's perceived distance.

\section{Conclusions and managerial implications}

Despite the growing number of recent studies addressing $\mathrm{m}$-shopping (Agrebi \& Jallais, 2015; GroB, 2015), much research remains to be done, particularly with the CEM framework in a mobile context. In this paper, evidence has been provided on the critical issue of the customer experience management (Palmer, 2010) for the mobile business and the moderating role of perceived distance from alternative physical retailers in an emerging market. Our results have emphasized several interesting findings for marketing managers and scholars concerning the development of mobile commerce in a huge potential market (the Mexican market, with 37.7 million smartphone users) (AMIPCI, 2016). The CEM framework is a useful one that is helpful in explaining $\mathrm{m}$-shopper satisfaction and intention to repurchase via mobile phone. M-shoppers continuously gather experiences when they interact with a firm, regardless of the channel through which they interact. M-shopper experience management is important since, in the mobile channel, communication and exchange are established virtually. Thus, the human, mechanical, and technical clues must be carefully and strategically managed by firms. According to this line of thought, providing evidence on how different clues influence m-shoppers' satisfaction is helpful for firms, suggesting general guidelines for deciding marketing strategies in mobile 
contexts in emerging markets. We would like to emphasize that m-vendors should try to offer an integral experience to their $\mathrm{m}$-shoppers, as many different factors can contribute to developing an overall image of a provider. In this sense, m-vendors should consider human, mechanical, and technical aspects as all of them contribute to satisfying customers, ultimately making them repeat their purchases. The positive effect of m-shopping satisfaction and intention to repurchase via mobile phone has been identified, regardless of psychologically perceived distance to alternative physical retailers. M-vendors should be aware of their employees' perceived behavior (reputation) in the mobile channel, the attractiveness and functional design of their selling platform, and the security and privacy assurances. However, psychological variables such as $\mathrm{m}$-shoppers' perceived distance (related to the perception of closeness to alternative physical retailers) can produce some differences in the CEM process. The $\mathrm{m}$-vendor's reputation is relevant for $\mathrm{m}$-shoppers who consider alternative physical retailers as being near, while the mechanical clue is valued by $\mathrm{m}$-shoppers who perceive alternative physical retailers as being distant. These results have indicated that a prerequisite for m-vendors to segment their target market is to consider the consumers' distance (near or far away) from bricks and mortar retailers (e.g. being aware of the relevance of applying geolocation to their mobile marketing strategies and employing location-based services). In agreement with the results found by $\mathrm{Heo}$ and Kim (2016), providing immediate information to customers based on their location makes mobile services competitive and can help to improve the customer experience and the perceived advantages of the mobile channel. According to our results, greater employee presence in mobile commerce (such as quicker responses to customer needs and problems with $\mathrm{m}$-shopping, and more warmth and enthusiasm in interactions with customers) could help to increase satisfaction with the experience of mobile purchases. Especially, direct marketing strategies (e.g. personalized text messaging) might be more helpful for m-shoppers who perceive retailers are near, rather than for m-shoppers who perceive retailers are far. The absence of physical and temporal barriers (an advantage in mobile commerce) is sometimes a tricky benefit, because consumers cannot collect sufficient clues to distinguish what their experience with an $\mathrm{m}$-vendor is. In those situations, employee reputation turns out to be a key clue (Joshi, 2014). However, in the case of $m$-shoppers who perceive alternative physical retailers are far away from them, excellent $m$-site design and practical advances in mobile device security are useful marketing tools for $\mathrm{m}$-vendors, so as to improve the $\mathrm{m}$-shopping experience of those customers that feel more isolated from alternative physical retailers (e.g. an m-site that reduces the search time to access personalized services, products, or information with regard to customer location). This study has contributed to management practice, as it has shown how mobile commerce overcomes not only specific and spatial location limitations, but also (psychologically) perceived drawbacks (such as perceived distance). It has also contributed to our understanding of the different clues that affect purchase experience, within a (CEM) framework that has shown to be flexible enough to understand a business model based on mobile technology in a geographically extensive country with an emerging market of interest to mobile business.

Several limitations of this study must be acknowledged. Firstly, the data for this study were collected from Mexican m-shoppers. Although these results are relevant in the analysis of a huge country, they must be corroborated by other geographically extensive emerging countries to test their generalizability (e.g. Brazil or China). Moreover, a future study should collect information with more representation from all age groups to be able to test the age effect on the proposed model. Secondly, heterogeneity in distance perceptions is recognized, since a non-objective measure of proximity (e.g. miles) to alternative physical 
retailers is considered. However, previous studies have affirmed that physical distance impacts on judgment and decision-making through its effects on psychological distance (Darke et al., 2016). In the future, a comparison between real and perceived measures of distance to stores would be advisable. Thirdly, there are many other clues that could affect $m$-shoppers' satisfaction and repurchase intention that should be considered in future studies. It would be particularly interesting to consider cross recommendations, quality, efficiency, or privacy. Fourthly, further research should extend the knowledge and application of CEM to other cultural or geographical contexts. Fifthly, it would be interesting to deepen the study of how other factors related to perceived distance affect the $\mathrm{m}$-shopper experience, such as neighborhood and a sense of isolation (Lavariega $\&$ Marichal, 2014). Sixthly, future studies should consider omni-channel customer behavior.

\section{References}

Agrebi, S., \& Jallais, J. (2015). Explain the intention to use smartphones for mobile shopping. Journal of Retailing and Consumer Services, 22(Jan), 16-23.

AMIPCI- Mexican Internet Association (2016). Study on electronic commerce development on mobile devices. Retrieved from: https://amipci.org.mx/images/ English_Estudio_Sobre_El_Desarrollo_del_ Comercio_Electronico_Movil.pdf

Bagozzi, R., \& Yi, Y. (1988). On the evaluation of structural equation models. Journal of the Academy of Marketing Science, 16(1), 74-94.

Benzarti, I. \& Mili, H. (2017). A Development Framework for Customer Experience Management Applications: Principles and Case Study. IEEE 14th International Conference on e-Business Engineering (ICEBE).

Berry, W., \& Carbone, L.P. (2006). Service clues and customer assessment of the service experience: lesson from marketing. Academy of Management Perspectives, 20(2), 43-57.

Blut, M., Chowdhry, N., Mittal, V., \& Brock, C. (2015). E-Service Quality: A Meta-Analytic Review. Journal of Retailing, 91(4), 679-700.

Bonera, M. (2011). The propensity of e-commerce usage: the influencing variables. Management Research Review, 34(7), 821-837.

Chi, T. (2018). Mobile Commerce Website Success: Antecedents of Consumer Satisfaction and Purchase Intention. Journal of Internet Commerce, 17(3), 189-215.

Choi, J., \& Nazareth, D. (2014). Repairing trust in an e-commerce and security context: an agent-based modeling approach. Information Management \& Computer Science, 22(5), 490-512.

Choi, J., Seol, H., Lee, S., Cho, H. \& Park, Y. (2008). Customer satisfaction factors of mobile commerce in Korea. Internet Research, 18(3), 313-335.

Chong, A. (2013). Understanding mobile commerce continuance intentions: an empirical analysis of Chinese consumers. Journal of Computer Information Systems, 53(4), 22-30.

Cohen, J. (1988). Statistical Power Analysis for the Behavioral Sciences. Lawrence Erlbaum Associates, Inc., Hillsdale, New Jersey.

Cyr, D., Head, M., \& Ivanov, A. (2006). Design aesthetics leading to m-loyalty in mobile commerce. Information \& Management, 43(8), 950-963.

Darke, P., Brady, M., Benedicktus, R. \& Wilson, A. (2016). Feeling Close From Afar: The Role of Psychological Distance in Offsetting Distrust in Unfamiliar Online Retailers. Journal of Retailing, 92(3), 287-299.

De Keyser, A., Lemon, K., Klaus, P., \& Keiningham, T. (2015). A Framework for Understanding 
and Managing the Customer Experience. MSI Working Paper No. 15-121. Cambridge, MA: Marketing Science Institute.

Deng, Z., Lu, Y., Wei, K., \& Zhang, J. (2010). Understanding customer satisfaction and loyalty. An empirical study of mobile instant messages in China. International Journal of Information Management, 30(4), 289-300.

Edelman, D., \& Singer, M. (2015), "Competing on Customer Journeys", Harvard Business Review, 93(Nov), 88-100.

Fatma, S. (2014). Antecedents and Consequences of Customer Experience Management- A Literature Review and Research Agenda. International Journal of Business and Commerce, 3(6), 32-49.

Fernández-Sabiote, E., \& Román, S. (2016). The multichannel customer's service experience: building satisfaction and trust. Service Business, 10(2), 423-445.

Fiore, A., \& Kim, J. (2007). An integrative framework capturing experiential and utilitarian shopping experience. International Journal of Retailing \& Distribution, 35(6), 421-442.

Flavián, C., \& Guinalíu, M. (2006). Consumer trust, perceived security and privacy policy: three basic elements of loyalty to a web site. Industrial Management \& Data Systems, 106(5), 601-620.

Forman, C., Ghose, A., \& Goldfarb, A. (2009). Competition between local and electronic markets: How the benefit of buying online depends on where you live. Management Science, 55(1), 47-57.

Fornell, C., \& Larcker, D. F. (1981). Structural equation models with unobservable variables and measurement error: Algebra and statistics. Journal of marketing research, 18(3), 382-388.

Genlin, Z., \& Jie, X (2015). Study of Customer Experience under the Circumstances of Mobile
Internet. International Journal of Multimedia and Ubiquitous Engineering, 10(2), 153-158.

González-Hernández, E., \& Orozco-Gómez, M. (2012). A segmentation study of Mexican consumers based on shopping centre attractiveness. International Journal of Retail \& Distribution Management, 4O(10), 759-777.

Grewal, D., Levy, M., \& Kumar, V. (2009). Customer Experience Management in Retailing: an organizing framework. Journal of Retailing, 85(1), 1-14.

GroB, M. (2015). Exploring the acceptance of technology for mobile shopping: an empirical investigation among Smartphone users. The International Review of Retail, Distribution and Consumer Research, 25(3), 215-235.

Hair, J.F., Hult, G.T.M., Ringle, C.M., Sarstedt, M., \& Thiele, K. O. (2017). Mirror, mirror on the wall: a comparative evaluation of composite-based structural equation modeling methods. Journal of the Academy of Marketing Science, 45(5), 616-632.

Hair, J., Hult, G., Ringle, C., \& Sarstedt, M. (2013). A primer on partial least squares structural equation modeling (PLS-SEM). London, UK: Sage Publications.

Hair, J., Ringle, C., \& Sarstedt, M. (2011). PLSSEM: Indeed a Silver Bullet. Journal of Marketing Theory and Practice, 19(2), 139-152.

Harris, L., \& Goode, M. (2004). The four levels of loyalty and the pivotal role of trust: a study of online service dynamics. Journal of Retailing, 80(2), 139-158.

Henseler, J., Hubona, G., \& Ray, P. (2016). Using PLS path modeling in new technology research: Updated guidelines. Industrial Management \& Data Systems, 116(1), 2-20.

Henseler, J., Ringle, C., \& Sarstedt, M. (2015). A new criterion for assessing discriminant validity 
in variance-based structural equation modelling. Journal of the Academy of Marketing Sciences, 43(1), 115-135.

Heo, J., \& Kim, K.J. (2016). Development of a scale to measure the quality of mobile locationbased services. Service Business, 1O(1), 1-30.

Hillman, S., \& Neustaedter, C. (2017). Trust and mobile commerce in North America. Computers in Human Behavior, 70(1), 10-21.

Homburg, C., Jozić, D., \& Kuehnl, C. (2015). Customer Experience Management: Toward Implementing an Evolving Marketing Concept. Journal of the Academy of Marketing Science, 45(3), 377-401.

INEGI - National Institute of Statistic and Geography (2018). Extensión de México. Retrieved from: http://cuentame.inegi.org.mx/territorio/ extension/default.aspx?tema $=\mathrm{T}$

Jaradat, M., \& Rababaa, M. (2013). Assessing Key Factor that Influence on the Acceptance of Mobile Commerce Based on Modified UTAUT. International Journal of Business and Management, 8(23), 102-112.

Jarvenpaa, S., Tractinsky, N., \& Vitale, M. (1999). Consumer trust in an Internet store. Information Technology Management, 1(1), 45-71.

Johnson, V.L., Kiser, A., Washington, R., \& Torres, R. (2018). Limitations to the rapid adoption of M-payment services: Understanding the impact of privacy risk on M-Payment services. Computers in Human Behavior, 79, 111-122.

Joshi, S. (2014). Customer experience management: An exploratory study on the parameters affecting customer experience for cellular mobile services of a telecom company. Procedia - Social Behavioral Sciences, 133(15), 392-399.

Joshi, S., Bhatia, S., Raikar, K. \& Pall, H. (2017). Customer Experience and associated customer behavior in end user devices and technologies (smartphones, mobile internet, mobile financial services). Journal of High Performance Computing and Networking, 10(1/2), 118-126.

Kamaladevi, B. (2010). Customer experience management in retailing. Business Intelligence Journal, 3(1), 37-54.

Katz, S., \& Byrne, S. (2013). Construal Level Theory of Mobile Persuasion. Media Psychology, 16(3), 245-271.

Khatun, F., Ruhul Islam, M. (2018). Security in Cloud Computing-Based Mobile Commerce. In: Kalam, A. Das, S. \& Sharma, K. (Eds.). Advances in Electronics, Communication and Computing. Lecture Notes in Electrical Engineering, 443. Springer, Singapore.

Kim, M., Chung, N., Lee, C., \& Preis, M. (2015). Motivations and use context in mobile tourism shopping: applying contingency and task-technology fit theories. International Journal of Tourism Research, 17(1), 13-24.

Kimbell, L. (2011). Designing for service as one way of designing services. International Journal of Design, 5(2), 41-52.

Kowalski, R., Giumetti, G., Schroeder, A., \& Lattanner, M. (2014). Bullying in the digital age: A critical review and meta-analysis of cyberbullying research among youth. Psychological Bulleting, 140(4), 1073-1137.

Kumar, V., Pozza, I., \& Ganesh, J. (2013). Revisiting the satisfaction - loyalty relationship: empirical generalizations and directions for future research. Journal of Retailing, 89(3), 246-262.

Kuo, Y., Wu, C., \& Deng, W. (2009). The relationships among service quality, perceived value, customer satisfaction, and post-purchase intention in mobile value-added services. Computers in Human Behavior, 25(4), 887-896. 
Lavariega, J., \& Marichal, J. (2014). The role of digital skills in the formation of generalized trust among Latinos and African Americans in the United States. Social Science Computer Review, 32(1), 3-17.

Lee, S., Yang, C., Lee, S., \& Lee, J. (2015). A study on the antecedents and consequences of satisfaction and dissatisfaction in web portal usage. Service Business, 9(3), 567-586.

Li, Y., \& Yeh, Y. (2010). Increasing trust in mobile commerce through design aesthetics. Computers in Human Behavior, 26(4), 673-684.

Liberman, N., Trope, Y., and Stephan, E. (2007), "Psychological distance", in Kruglanski, A.W. and Higgins, E.T. (Eds.), Social psychology: Handbook of basic principles. New York: Guilford Press.

Lin, H., \& Wang, Y. (2006). An examination of the determinants of customer loyalty in mobile commerce contexts. Information \& Management, 43(3), 271-282.

Lin, Z., \& Bennett, D. (2014). Examining retail customer experience and the moderation effect of loyalty programmes. International Journal of Retail \& Distribution Management, 42(10), 929-947.

Lipkin, M. (2016). Customer experience formation in today's service landscape. Journal of Service Management, 27(5), 678-703.

Luarn, P., \& Lin, H. (2005). Toward an understanding of the behavioural intention to use mobile banking. Computers in Human Behavior, 21(6), 873-891.

Mai, N., Yoshi, T., \& Tuan, N. (2014). Determinants of online customer satisfaction in an emerging market - a mediator role of trust. International Journal of Contemporary Management, 13(1), 8-30.

Malhotra, N., Kim, S., \& Patil, A. (2006). Common method variance in IS research: A comparison of alternative approaches and a reanalysis of past research. Management Science, 52(12), 1865-1883.

Mbama, C.I. \& Ezepue, P.O. (2018). Digital banking, customer experience and bank financial performance: UK customers' perceptions. International Journal of Bank Marketing, 36(2), 230-255.

Memery, J., Angell, R., Megicks, P., \& Lindgreen, A. (2015). Unpicking motives to purchase locallyproduced food: analysis of direct and moderation effects. European Journal of Marketing, 49(7/8), 1207-1233.

Mohr, L., \& Bitner, M. (1995). The role of employee effort in satisfaction with service transactions. Journal of Business Research, 32(3), 239-252.

Montoya-Weiss, M., Voss, G., \& Grewal, D. (2003). Determinants of online channel use overall satisfaction with a relational, multichannel service provider. Journal of the Academy of Marketing Science, 31(4), 448-458.

Morosan, C. (2014). Toward an integrated model of adoption of mobile phones for purchasing ancillary services in air travel. International Journal of Contemporary Hospitality Management, 26(2), 246-271.

Pallant, J. (2016). SPSS survival manual: a step by step guide to data analysis using IBM SPSS, 6. th edn.

Palmer, A. (2010). Customer experience management: a critical review of an emerging idea. Journal of Services Marketing, 24(3), 196208.

Pandey, S. \& Chawla, D. (2018). Online customer experience (OCE) in clothing e-retail: Exploring OCE dimensions and their impact on satisfaction and loyalty - Does gender matter?. International Journal of Retail \& Distribution Management, 46(3), 323-346. 
Pappas, I., Pateli, A., Giannakos, M., \& Chrissikopoulos, V. (2014). Moderating effects of online shopping experience on customer satisfaction and repurchase intentions. International Journal of Retail \& Distribution Management, 42(3), 187-204.

Perea-Monsuwé, T., Dellaert, B., \& De Ruyter, K (2004). What drives consumers to shop online? A literature review. International Journal of Service Industry Management, 15(1), 102-121.

Piacentini, M., \& Cui, C. (2010). Multicultural perspectives in customer behaviour. New York, NY: Routledge.

Puccinelli, N.M., Goodstein, R.C., Grewal, D., Price, R., Raghubir, P. \& Stewart, D. (2009). Customer Experience Management in Retailing: Understanding the Buying Process. Journal of Retailing, 85(1), 15-30.

Qureshi, I., Fang, Y., Ramsey, E., McCole, P., Ibbotson, P. \& Compeau, D. (2009). Understanding online customer repurchasing intention and the mediating role of trustan empirical investigation in two developed countries. European Journal of Information System, 18(3), 205-222.

Ranjan, K., \& Read, S. (2016). Value co-creation: concept and measurement. Journal of the Academy of Marketing Science, 44(3), 290-315.

Ray, S., Ow, T., \& Kim, S. (2011). Security assurance: how online service providers can influence security control perceptions and gain trust. Decision Sciences, 42(2), 391-412.

San-Martín, S., Prodanova, J., \& Jiménez, N. (2015). The impact of age in the generation of satisfaction and WOM in mobile shopping. Journal of Retailing and Consumer Services, 23, 1-8.
San-Martín, S., Prodanova, J., \& López, B. (2016). What makes services customers say "buy it with a mobile phone"?. Journal of Services Marketing, 30(6), 601-614.

Schierz, P., Schilke, O., \& Wirtz, B. (2010). Understanding consumer acceptance of mobile payment services: empirical analysis. Electronic Commerce Research and Applications, 9(3), 209216.

Sharma, P., Wu, Z., \& Su, Y. (2016). Role of personal cultural orientations in intercultural service encounters. Journal of Services Marketing, 30(2), 223-237.

Simons, L., Hampe, J., \& Guldemond, N. (2014). ICT supported healthy lifestyle interventions: design lessons. Electronic Markets, 24(3), 179-192.

Slade, E., Dwivedi, Y., Piercy, N., \& Williams, M. (2015). Modeling Consumers' Adoption Intentions of Remote Mobile Payments in the United Kingdom: Extending UTAUT with Innovativeness, Risk, and Trust. Psychology\&Marketing, 32(8), 860-873.

Sukwadi, R. (2015). Utilizing Customer Experience Management Framework to Create a Delightful Service Experience. International Journal of Industrial Engineering and Management, 6(1), 29-42.

Voorhees, C., Brady, M., Calantone, R., \& Ramirez, E. (2016). Discriminant validity testing in marketing: an analysis, causes for concern, and proposed remedies. Journal of the Academy of Marketing Science, 44(1), 119-134.

Weber, M. \& Elferink, A.O. (2017). CX - Liner: design and development of a diagnostic tool for customer experience management in SMEs. Acta Technica Corviniensis - Bulletin of Engineering, 10(1), 4-11. 


\section{Appendix}

Table 8

\section{Items description}

\begin{tabular}{|c|c|c|}
\hline Variables & Desc & tion \\
\hline \multirow{5}{*}{$\begin{array}{l}\text { Human dimension } \\
\text { (employees' } \\
\text { reputation) }\end{array}$} & V1 & Most consumers think that this $\mathrm{m}$-site has good employees. \\
\hline & $\mathrm{V} 2$ & This $\mathrm{m}$-site/vendor is acknowledged as a leader in its sector. \\
\hline & $\mathrm{V} 3$ & This $\mathrm{m}$-site/vendor is well-known for its human resources. \\
\hline & V4 & This $\mathrm{m}$-site/vendor shows concern about its customers. \\
\hline & V5 & This m-site/vendor has a good reputation because of its employees. \\
\hline \multirow{4}{*}{$\begin{array}{l}\text { Mechanical } \\
\text { dimension } \\
\text { (m-site design) }\end{array}$} & V6 & This m-site/vendor contains images that make a better experience of shopping. \\
\hline & V7 & This m-site/vendor has an attractive, modern, and professional design. \\
\hline & V8 & The advertising I receive from this $\mathrm{m}$-site/vendor adapts to my situation and interests. \\
\hline & V9 & This $\mathrm{m}$-site/vendor allows me to ask for personalized products/services. \\
\hline \multirow{4}{*}{$\begin{array}{l}\text { Technical } \\
\text { dimension } \\
\text { (m-site security) }\end{array}$} & V10 & $\begin{array}{l}\text { This m-site/vendor assures that the risk of abusing my personal information is low when I pay via a } \\
\text { mobile. }\end{array}$ \\
\hline & V11 & This $\mathrm{m}$-site/vendor makes sure that the risk of abusing my banking information is low. \\
\hline & V12 & $\begin{array}{l}\text { This m-site/vendor makes sure that the risk of an unauthorized person accessing my m-payment process } \\
\text { is low. }\end{array}$ \\
\hline & V13 & I think that the m-payment services of this $\mathrm{m}$-site/vendor are secure. \\
\hline \multirow{7}{*}{ Satisfaction } & V14 & I am satisfied with the m-site/vendor's process for managing my shopping. \\
\hline & V15 & I am happy with the products/services I have bought from this $\mathrm{m}$-site/vendor. \\
\hline & V16 & The shopping experience with this $\mathrm{m}$-site/vendor has been satisfactory. \\
\hline & V17 & I am satisfied with the information that the m-site/vendor gave me in this shop. \\
\hline & V18 & My shopping expectations have been met by this m-site/vendor. \\
\hline & V19 & I think I made the right decision by using this $\mathrm{m}$-site. \\
\hline & V20 & I am generally happy with having bought from this m-site/vendor. \\
\hline \multirow{3}{*}{$\begin{array}{l}\text { Repurchase } \\
\text { intention }\end{array}$} & V21 & I will consider buying from this $\mathrm{m}$-site/vendor instead of other channels. \\
\hline & V22 & I think I will continue buying from this $\mathrm{m}$-site/vendor even if the price is higher than in other channels. \\
\hline & V23 & I will repeat purchases from this $\mathrm{m}$-site/vendor when I have the opportunity. \\
\hline
\end{tabular}




\section{About the Authors:}

1. Sonia San-Martín, Ph.D. Program in Business Administration, University of Burgos, Burgos, Spain.

E-mail:sanmargu@ubu.es

\section{ORCIID}

\section{(iD 0000-0002-5030-9669}

2. Nadia H. Jiménez, Ph.D. Program in Business Administration and Management, University of Burgos, Burgos, Spain. E-mail: nhjimenez@ubu.es

\section{ORCIID}

iD 0000-0001-5771-2971

3. Nuria Puente, Ph.D. Program in Communication Science, Nebrija University, Madrid, Spain.

E-mail: nuria.puente.dominguez@ui1.es

\section{ORCID}

iD $0000-0003-0483-2691$

San-Martín, S., Jiménez, N.H. \& Puente, N. (2016): “A m-CEM framework to understand the factors that contribute to a satisfactory and lasting experience”, XXVIII AEMARK Marketing Congress Proceedings 2016, pp.515-528. León, 7-9 September 2016. ISBN: 978-84-16701-48-3

\section{Contribution of each author:}

\begin{tabular}{|c|c|c|c|}
\hline Contribution & Sonia San-Martín & Nadia H. Jiménez & Nuria Puente \\
\hline 1. Definition of research problem & $\sqrt{ }$ & $\sqrt{ }$ & \\
\hline 2. Development of hypotheses or research questions (empirical studies) & $\sqrt{ }$ & $\sqrt{ }$ & $\sqrt{ }$ \\
\hline 3. Development of theoretical propositions (theoretical work) & & & $\sqrt{ }$ \\
\hline 4. Theoretical foundation/Literature review & & & $\sqrt{ }$ \\
\hline 5. Definition of methodological procedures & $\sqrt{ }$ & & \\
\hline 6. Data collection & & $\sqrt{ }$ & \\
\hline 7. Statistical analysis & & $\sqrt{ }$ & \\
\hline 8. Analysis and interpretation of data & $\sqrt{ }$ & $\sqrt{ }$ & $\sqrt{ }$ \\
\hline 9. Critical revision of the manuscript & $\sqrt{ }$ & $\sqrt{ }$ & $\sqrt{ }$ \\
\hline 10. Manuscript writing & $\sqrt{ }$ & & \\
\hline 11. Other (please specify which) & & & \\
\hline
\end{tabular}


Sonia San-Martín / Nadia Jiménez / Nuria Puente 